\title{
Reflections on Dictionaries Designed to Assist Users with Text Production in a Foreign Language
}

\author{
Sven Tarp, Centre for Lexicography, Aarhus School of Business, Aarhus, \\ Denmark(st@asb.dk)
}

\begin{abstract}
After a discussion of a selected part of the existing theoretical literature, the concept of foreign-language text production is analysed within the framework of the broader concept of the foreign-language learning process. Two main types of foreign-language text production are discussed, i.e. text production with and without an outline in the learner's mother tongue, followed by an analysis of the kind of assistance dictionaries can provide to the user. The main conclusion drawn from this discussion is that a dictionary designed to assist a user with both types of text production should include both an $\mathrm{L}_{1}-\mathrm{L}_{2}$ word list and an $\mathrm{L}_{2}$ (or $\mathrm{L}_{2}-\mathrm{L}_{1}$ ) word list. On this basis, a proposal for the lexicographic data that should be included in the respective word lists is presented, and this data is then compared with the data needed to assist the user in foreign-language text reception. The conclusion is that it is quite possible to conceive bifunctional dictionaries that can provide assistance for both foreign-language text production and foreign-language text reception.
\end{abstract}

Keywords: LEXICOGRAPHY, LEARNER'S LEXICOGRAPHY, LEARNER'S DICTIONARIES, LEXICOGRAPHIC FUNCTIONS, COMMUNICATION-ORIENTATED FUNCTIONS, FOREIGNLANGUAGE TEXT RECEPTION, FOREIGN-LANGUAGE TEXT PRODUCTION, USER CHARACTERISTICS, USER NEEDS, USER SITUATIONS, LEXICOGRAPHIC DATA

Opsomming: Gedagtes oor woordeboeke ontwerp om gebruikers te help met teksprodukise in ' $n$ vreemde taal. Na 'n bespreking van ' $n$ uitgesoekte deel van die bestaande teoretiese literatuur, word die konsep van vreemdetaalteksproduksie ontleed binne die raamwerk van die breër konsep van die aanleerposes van 'n vreemde taal. Twee hooftipes vreemdetaalteksproduksie word bespreek, nl. teksproduksie met en sonder 'n oorsig van die aanleerder se moedertaal, gevolg deur 'n ontleding van die soort hulp wat woordeboeke aan die gebruiker kan verleen. Die hoofgevolgtrekking gemaak uit hierdie bespreking is dat 'n woordeboek wat ontwerp is om 'n gebruiker met altwee tipes teksproduksie te help, sowel 'n L1-L2-woordelys as 'n L2- (of L2-L1) woordelys behoort in te sluit. Op hierdie basis word 'n voorstel van die leksikografiese data wat in die onderskeie woordelyste ingesluit behoort te word, aangebied, en hierdie data word dan vergelyk met die data benodig om die gebruiker by vreemdetaalresepsie te help. Die gevolgtrekking is dat dit heeltemal moontlik is om bifunksionele woordeboeke te bedink wat hulp kan verleen met sowel vreemdetaalteksproduksie as vreemdetaalteksresepsie.

* This article is a slightly revised version of the closing paper read at the Seminar on Learners' Dictionaries presented by the African Association for Lexicography at the University of Pretoria, Pretoria, Republic of South Africa, 11-12 November 2002.

Lexikos 14 (AFRILEX-reeks/series 14: 2004): 299-325 
Sleutelwoorde: LEKSIKOGRAFIE, AANLEERDERSLEKSIKOGRAFIE, AANLEERDERSWOORDEBOEKE, LEKSIKOGRAFIESE FUNKSIES, KOMMUNIKASIEGEORIËNTEERDE FUNKSIES, VREEMDETAALTEKSRESEPSIE, VREEMDETAALTEKSPRODUKSIE, GEBRUIKERSEIENSKAPPE, GEBRUIKERSBEHOEFTES, GEBRUIKERSITUASIES, LEKSIKOGRAFIESE DATA

\section{Introduction}

In modern theory of lexicographic functions, one of the basic communicationorientated functions of dictionaries is to assist users in solving problems related to text production in a foreign language (Tarp 1992, 1994, 1995, 1998, 2000, 2003, Bergenholtz and Tarp 2002, 2003, 2004a, 2004b). But what exactly is meant by text production in a foreign language? How does it take place? What is the typology of the users who would be expected to consult a dictionary in order to solve problems related to this kind of text production? What are these problems? And how can dictionaries assist users in solving them? These are fundamental questions of both theoretical and practical importance that must be answered in order to further develop the functional theory of lexicography. This article will try to advance in this direction. It will argue that, in terms of dictionaries, foreign-language text production can only be understood within the framework of learner's lexicography in the broad sense of the word. It will put forward a proposal for a general model of a dictionary designed to assist with the production of foreign-language texts. And finally it will show how such a dictionary can easily be developed also to serve the reception of foreignlanguage texts, i.e. to combine at least two different lexicographic functions.

\section{Theoretical contributions}

Some ten years ago, the German lexicographer Joachim Mugdan (1992a, 1992b) shocked quite a number of lexicographers when he argued that future $\mathrm{L}_{2}-\mathrm{L}_{1}$ dictionaries, in order to avoid the production of too many dictionaries for each pair of languages, should be designed in such a way that they could also assist $\mathrm{L}_{1}$ users in solving problems related to text production in $\mathrm{L}_{2}$. At that time the so-called "active-passive" theory reigned in the world of lexicography (Kromann et al. 1984, 1991). This theory, among others, included $\mathrm{L}_{2}$ text production in the concept of $\mathrm{L}_{1}-\mathrm{L}_{2}$ "translation". Hence, according to this theory, and the prejudices of many lexicographers, assistance with $\mathrm{L}_{2}$ text production should be provided in an $\mathrm{L}_{1}-\mathrm{L}_{2}$ dictionary, i.e. the opposite view of the one proposed by Mugdan. He, however, was not the first lexicographer to put forward such an unorthodox idea. Fifteen years earlier, his fellow countryman F.J. Hausmann had suggested something similar in his famous book on modern French dictionaries (Hausmann 1977). Hausmann recommended that free text production in a foreign language should be supported by a monolingual $\mathrm{L}_{2}$ dictionary and that bilingual dictionaries generally should be used as late as possible. 
Hausmann made a clear distinction between free foreign-language production and translation-related production (Hausmann 1977: 145. Translated by ST):

Production of a foreign-language text can, as free production, be based on one's own thoughts or can be transferred from a mother-tongue text into the foreign language $\left(\mathrm{L}_{1}-\mathrm{L}_{2}\right.$ translation).

Both Mugdan's and Hausmann's observations and recommendations are of great value for the development of a theory of the lexicographic function of "assistance to foreign-language production". Even more important and valuable are, however, the reflections made by the Russian lexicographer L.V. Shcherba in 1940. Although Shcherba apparently considered lexicography a subdiscipline of linguistics, he has without doubt the merit of being the founder of a general theory of lexicography. Shcherba discussed the production of foreign-language texts within the framework of the language-learning process. According to the Danish scholar Hans Kristian Mikkelsen who has studied Shcherba's original Russian works, Shcherba was generally strongly opposed to the contrastive methodology in foreign-language didactics because it could contribute to "a mixed bilingualism due to numerous transfers from $\mathrm{L}_{1}$ " and therefore "only goes for $\mathrm{L}_{2}$ learning at the beginner's level" (Mikkelsen 1992: 34). In his famous essay on a general theory of lexicography, Shcherba (1940: 341) once more stressed this point of view:

Any true pedagogue advises students to discard translating dictionaries as soon as possible and switch to the defining dictionary of the foreign language. A translating dictionary, then, is only useful for beginning foreign language students.

Shcherba was extremely critical of the existing bilingual dictionaries, above all because they did not help the user to grasp the meaning of the foreign word. Although he pointed out that the faults of these dictionaries could be partly eliminated by adding various notes and examples, he himself preferred what he called a radical solution to the problem, namely the compilation of "foreign defining dictionaries in the students' native language". These dictionaries should mainly contain definitions - or explanations - of the foreign words, written in the user's own language. Shcherba (1940: 341), however, also accepted mother-tongue equivalents in those cases "when this would simplify definition and would not be detrimental to a full understanding of the foreign word's true nature".

From the very way this whole idea is presented, it becomes clear that the defining dictionary proposed by Shcherba is not just a traditional dictionary for the purpose of foreign-language reception, but mainly a dictionary designed to assist the assimilation of the foreign-language system (lexis and grammar) and the production of texts in this language. Until this new type of dictionary was developed, Shcherba considered the translation dictionary a "malum necessarium". Although he himself was a polyglot who easily assimilated a new language, Shcherba on the other hand was very much aware of the fact that for- 
eign-language students at a beginner's level would have big difficulties in using such a dictionary due to their limited knowledge of the foreign language. In this way he introduced a very important distinction, in terms of different lexicographic needs, between users at a beginner's level and more experienced and advanced users (Shcherba 1940: 341-342):

However, a special type of translating dictionary must still be retained for the people who do not know the foreign language very well, but nevertheless need to translate something into that language from time to time. Generally speaking, the basic rule of a competent foreign-language teaching methodology is that one should not - even mentally — translate from one's own native language, but try to think in the foreign language within the limits of one's knowledge, referring when necessary to ideological or synonym dictionaries as well as to good foreign defining dictionaries, but by no means to translating dictionaries. However, when applied to practical life, this presupposes a rather high level of skill in the foreign language.

Here it must be noted that when Shcherba speaks about translation in the above quotation, he apparently does not mean translation in the narrow sense of the word. According to Mikkelsen (1992) and Mugdan (1992a), for Shcherba real translation seems to be a creative activity that generally should be carried out without the consultation of dictionaries. Shcherba's idea was that when you have understood a text, then you would also be able to translate it and find the corresponding equivalents. So the use of the word translation in the above quotation rather seems to refer to a situation where the student first thinks in his/ her own language and then "translates" it and produces a text in the foreign language. This theoretical distinction between two different types of foreignlanguage text production, apart from the one related to real translation, has wide-ranging consequences for practical lexicography. Shcherba (1940: 342) himself suggests what he calls a "special type of dictionary" in order to cover the needs of the foreign-language students at a beginner's level. This dictionary should enable these users "to translate non-fictional texts into the foreign language without making gross mistakes" and, as such, it should provide exact indications on how to translate mother-tongue words "in various contexts in order to be understood and to avoid appearing ridiculous". Shcherba (1940: 342) summarises his ideas as follows:

To summarise this section, I repeat what I said in the preface to my dictionary: for every pair of languages, four dictionaries are needed. Two foreign defining dictionaries with explanations in the native language of the user are absolutely necessary, and depending on actual needs, two translating dictionaries of the special type indicated above, from the native language into the foreign language.

Although he speaks of four different types of dictionaries, what Shcherba really does in his important contribution to lexicography is to discuss different lexicographic functions, i.e. giving assistance to users with different mother tongues and levels of $\mathrm{L}_{2}$ mastery in solving problems related to different user situations. This was a big step forward for lexicography. 


\section{Who needs assistance with foreign-language text production?}

As could be seen in the previous section, Shcherba only discussed the production of foreign-language texts within the framework of the language-learning process. This approach, however, can be extended to all kinds of foreign-language text production. Who else than foreign-language learners, in the broad sense of the word, would be expected to produce texts in a foreign language? Ever since the publication of the first edition of the Oxford Advanced Learners' Dictionary in 1948, the term "advanced learner" has been commonly accepted and used both within lexicography and linguistics. This term gives a broad sense to the meaning of the word "learner". The learning of a foreign language is normally a life-long process. Very few people succeed in reaching the same degree of mastery of their second language as is the case with their mother tongue. And if they eventually do, they can no longer be considered to be speaking in a foreign language. Hence, although it is not common in theoretical literature, it seems quite acceptable to analyse and discuss lexicographic assistance to foreign-language text production within the framework of learner's lexicography. This, however, at the same time simplifies and complicates the problem. It simplifies it because it is no longer necessary to distinguish between "normal" $\mathrm{L}_{2}$ production and learner-related $\mathrm{L}_{2}$ production. And it complicates it because it requires an analysis of the concept of a learner.

Tarp (2003) has put forward the following elements aimed at a determination of a learner profile and the general circumstances, in which the foreignlanguage learning takes place:

(a) Proficiency level

(b) Adult or child

(c) Emigrant or other type of learner

(d) "Joint" or separate culture

(e) Level of general culture

(f) Conscious or spontaneous learning

(g) Learning inside or outside the language area

(h) Learning being exposed or unexposed to the mother tongue

(i) Learning with or without contrastive methodology

(j) Learning related or unrelated to a specific textbook or didactic system

(k) Learning related or unrelated to a particular topic (economy, history, culture etc.)

All these elements are important in order to draw up a complete characteristic of the user profile for a specific dictionary. If the user is a child, for instance, the vocabulary should be more reduced, the definitions and the metalanguage easier, the structures and layout simpler, etc. If the learner's culture is different from that of the foreign language community, notes on cultures should be added. If the learning process is related to a specific textbook, the vocabulary of the dictionary should be adapted to that of the textbook. However, for the pur- 
pose of this article points (a) and (i) are the most interesting. As has been seen in the previous section, both Shcherba and Hausmann give recommendations as to how to study a foreign language or produce an $\mathrm{L}_{2}$ text. However, this sort of recommendations is not the task of lexicography, but of linguistics and language didactics. However sympathetic Shcherba's resistance to the contrastive methodology in language learning might seem, the task of lexicography is or should always be to study the real language-learning process followed by the intended users and to support this process by means of dictionaries, whether or not it is based on the contrastive method of language learning. This means that if the intended user group use this method, a bilingual dictionary of the sort that Shcherba dislikes is indispensable. The task of dictionaries - and lexicography - is to satisfy the needs of a specific group of users in terms of helping them to solve problems related to a specific user situation. And if this situation is due to an undesirable methodology, lexicography nevertheless fulfils its function as long as it does not conflict with more general ethical principles.

\section{What is foreign-language text production?}

The foreign-language learning process can be illustrated in the following schematic way:

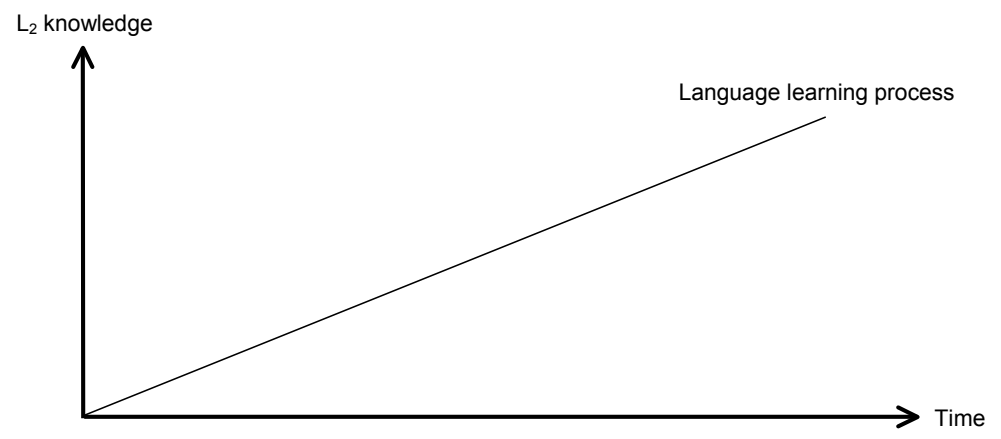

Illustration 1: Foreign-language learning process

Of course, this process can be slower or quicker depending on the concrete learner's talent and efforts. Furthermore, the real line will not be a straight one, but will include periods with slow growth followed by sudden dialectical jumps when quantity transforms itself into quality, i.e. when the passive vocabulary or grammar becomes active. And in the beginning of the process, the foreign-language knowledge will most probably grow quicker and then slower and slower, thus forming a curve. Moreover, every learner will have his/her own individual curve. Nevertheless, at an abstract level, the above schema is fully acceptable for the purpose of this article, i.e. to detect some lexicographically relevant problems in the language-learning process. 
Theoretically, it is possible to separate various phases in the $\mathrm{L}_{2}$ learning process and make dictionaries especially designed to cover learners' needs in each of these phases. A production dictionary conceived for the very first beginner's phase would, for example, require a more reduced vocabulary, fewer senses of the words' meaning, more basic and less specific grammatical data, fewer collocations etc. than a dictionary conceived for more experienced users, and so on. From an economic and logistic point of view, however, it would often be undesirable to produce a big number of highly specialised dictionaries that would only be helpful to the user in a limited period of the $\mathrm{L}_{2}$ learning process. Dictionaries will, therefore, often be designed to cover several, specific phases, i.e. a much longer period of the learning process, thus combining the data needed to assist the user group in various phases. But in order to achieve a successful combination of data it is first of all necessary to have a thorough understanding of what is meant by foreign-language text production. In this respect, Tarp (1992) separated three different types of $\mathrm{L}_{2}$ text production, each with its own characteristics:

(a) Translation-related $\mathrm{L}_{2}$ text production

(b) $\mathrm{L}_{2}$ text production based on an outline in $\mathrm{L}_{1}$

(c) Free $\mathrm{L}_{2}$ text production without an outline in $\mathrm{L}_{1}$

Translation-related $\mathrm{L}_{2}$ text production is a special type of $\mathrm{L}_{2}$ production, which makes up the third phase of the $\mathrm{L}_{1}-\mathrm{L}_{2}$ translation process composed of $\mathrm{L}_{1}$ reception, $\mathrm{L}_{1}-\mathrm{L}_{2}$ transfer and $\mathrm{L}_{2}$ production. Having been thoroughly discussed and analysed by Tarp (2002), it is not the topic of this article.

$L_{2}$ text production based on an outline in $L_{1}$ is equivalent to what Shcherba called "translation" in his essay discussed in section 2. This user situation has a variety of specific expressions and is highly individualised. First of all, there is the situation where the learner, inside his/her brain, first formulates a phrase in the mother tongue and then "translates" it into the foreign language. Then there is the situation where the learner first formulates a general idea in the mother tongue and then reconstructs it in the foreign language. And, finally, there is the situation where the learner tries to think in the foreign language but due to the limited $\mathrm{L}_{2}$ vocabulary frequently encounters concepts that he/she only knows how to express in the mother tongue and therefore has to "translate". Furthermore, one and the same learner would not necessarily use only one of these methods, but will most probably switch between them depending on the more or less complicated character of the phrases to be expressed in the foreign language.

Free $L_{2}$ text production without an outline in $L_{1}$ is the user situation where the learner tries to express him-/herself only on the basis of thinking in the foreign language. It will normally require a relatively high level of mastery of $\mathrm{L}_{2}$.

The above distinction between foreign-language text production with an outline in the mother tongue and free foreign-language production without such an outline is of wide-ranging theoretical and practical importance. As has 
been seen, Shcherba, Hausmann and Mugdan lay great emphasis on free $\mathrm{L}_{2}$ text production without an outline in $\mathrm{L}_{1}$. But for the majority of $\mathrm{L}_{2}$ learners the real user situation when producing a text in a foreign language is most probably another one. In this regard, Tarp (1992: 39) concluded:

It rather seems that "production in a foreign language" should be considered a process that in the beginning (i.e. with the learner at a beginner's level) is based on the "producer's" mother tongue (i.e. with an outline in the mother tongue) and then gradually is getting based on the foreign language (i.e. without an outline in the mother tongue) in correspondence with the "producer's" still greater mastery of this language. In other words: that "production in a foreign language" for the big majority takes place as a combination of production with and without an outline in the mother tongue.

This way of understanding text production related to the foreign-language learning process can be illustrated in the following schematic way:

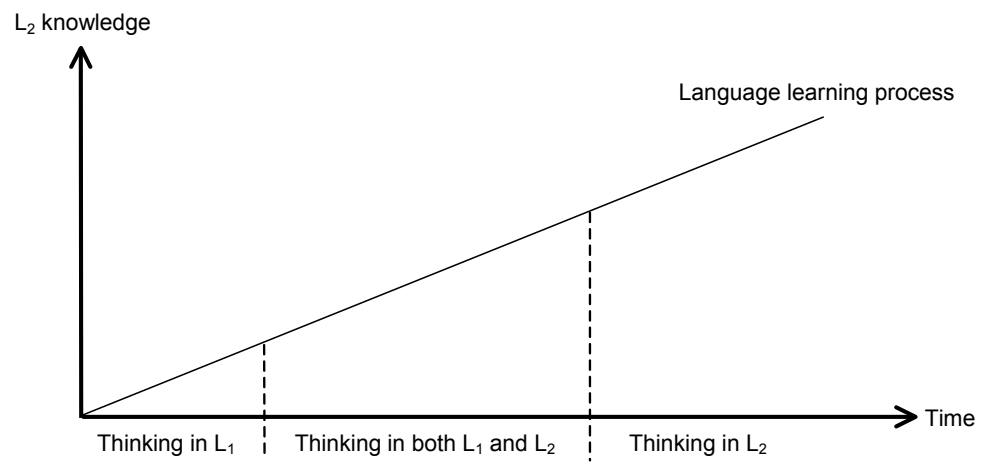

Illustration 2: Text production related to foreign-language learning

Once more, it is evident that the duration of the various phases is unique for each individual learner and might depend on a number of factors such as talent, efforts and methodology. If the contrastive method is used, the phase of $\mathrm{L}_{1}$ thinking would, for instance, be supposed to last much longer. On the other hand, if the user is following Shcherba's recommendations, he/she might start thinking in the foreign language from the very first day of the learning process in order to formulate simple phrases in $\mathrm{L}_{2}$. But, of course, if more complex phrases have to be expressed for one reason or the other, this type of learner will also have to switch to the bilingual method, at least for the time being.

\section{Lexicographic assistance to foreign-language text production}

The above observations lend a fresh perspective to the question of lexicographic assistance to text production related to the foreign-language learning process. 
In order to cover the user's real needs, production-related learner's dictionaries should allow him/her to make consultations through the language(s) relevant in each phase of the learning process. In the first phase when thinking primarily takes place in the mother tongue, the dictionary must provide for consultations through $\mathrm{L}_{1}$. In the advanced phase when thinking is mainly done in the foreign language, the dictionary must in the same way provide for consultations through $\mathrm{L}_{2}$. However, in the long phase in between where thinking takes place in both $\mathrm{L}_{1}$ and $\mathrm{L}_{2}$, the dictionary has to provide for consultations in both languages if it wants to cover the user's real needs. This can be summarised in the following way:

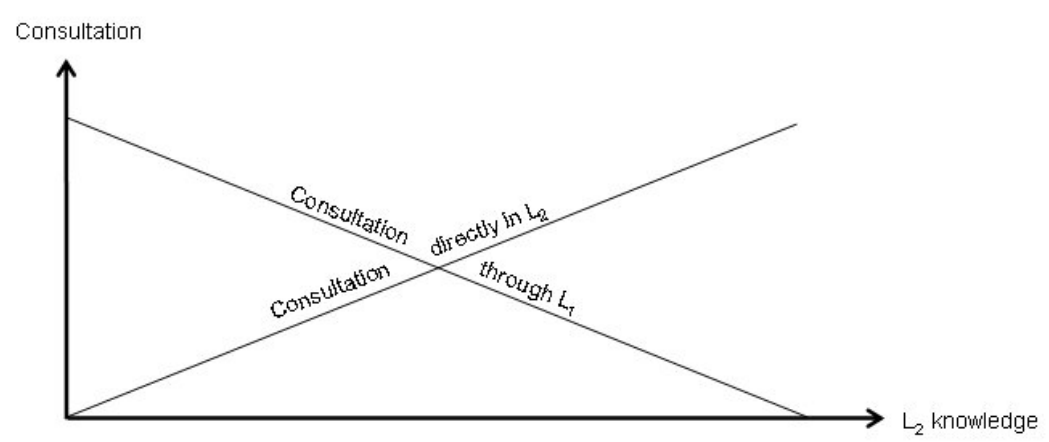

Illustration 3: Consultation of dictionaries to assist $\mathrm{L}_{2}$ text production

It goes without saying that this complex character of the foreign-language text production has huge consequences for learner's lexicography. The important conclusion to be drawn from this is that - with the exception of dictionaries designed only to serve users who exclusively base themselves in the mother tongue or the foreign language - dictionaries conceived to assist $\mathrm{L}_{2}$ text production should incorporate both a bilingual $\mathrm{L}_{1}-\mathrm{L}_{2}$ section and a section with $\mathrm{L}_{2}$ lemmata, either in one or two volumes. The big challenge for lexicography is to provide a theory that can lead to the making of such dictionaries.

\subsection{The lexicographic journey from $L_{1}$ to $L_{2}$}

It has already been mentioned that if users follow the contrastive method in language learning, they will need a bilingual $\mathrm{L}_{1}-\mathrm{L}_{2}$ dictionary of the type Shcherba detested. However, Shcherba himself admitted that other learners at beginners' level would also have big difficulties in proceeding directly to the foreign words in an $\mathrm{L}_{2}$ dictionary and he therefore made provision for improving the traditional $\mathrm{L}_{1}-\mathrm{L}_{2}$ dictionary and for creating a "special type of dictionary". Shcherba died in 1944 before he had the opportunity to put this idea into practice. So it is actually unknown how it would have been conceived in 
detail. But it is, nevertheless, a question whether Shcherba did not betray his own opposition to mixed bilingualism with this proposal. There are a number of reasons why bilingual $\mathrm{L}_{1}-\mathrm{L}_{2}$ dictionaries might never be the most suitable to provide information on $\mathrm{L}_{2}$.

What information do the users need in order to produce a correct text in $\mathrm{L}_{2}$ ? First of all, they need the foreign word, its orthography, pronunciation, part of speech and gender. Then they need confirmation that the word in question has the right meaning or sense for the concrete purpose. Furthermore, they need synonyms, antonyms, hyponyms etc. as well of pragmatic and even cultural information in order to vary the style and assure that the word is used in the correct context. And finally, of course, they need information on inflectional morphology and syntactical properties which also includes word combinations such as collocations, idioms and proverbs.

This is a very big amount of lexicographic data that would have to be addressed to the "passive side" of the word list. Of course, if the users proceed directly from a specific mother-tongue word to a foreign-language word with the necessary meaning differentiation, they can be more or less sure that the meaning or sense of the latter is the right one in the specific context and can be used to produce the $\mathrm{L}_{2}$ text in question. Although this does not necessarily mean that the complete meaning of the $\mathrm{L}_{2}$ word is expounded and, therefore, may contribute to a "mixed bilingualism", the partial meaning or sense provided through the $\mathrm{L}_{1}-\mathrm{L}_{2}$ word list is sufficient for the purpose of foreign-language text production. Furthermore, it is also relatively easy to include data providing information on orthography, pronunciation, gender and part of speech in an $\mathrm{L}_{1}-\mathrm{L}_{2}$ word list, and the same applies to synonyms, antonyms, hyponyms, collocations, idiom, proverbs etc. Foreign-language collocations, idioms and proverbs that are not direct translation equivalents of mothertongue collocations etc. would, of course, be missing, thus contributing to a poorer language and style. Pragmatic data on $\mathrm{L}_{2}$ could also easily be given in the $\mathrm{L}_{1}-\mathrm{L}_{2}$ word list, at least if they are presented in a codified way, but it would be much more complicated to include items providing cultural information related to $\mathrm{L}_{2}$ in such a word list. However, when it comes to inflectional morphology and, especially, syntactic properties, the knowledge of which, together with the word, is the starting point for any text production, the problems become really big.

Even if the lexicographer - like Shcherba - who just wants to help users to produce "non-fictional" texts in $\mathrm{L}_{2}$ in order "to be understood and to avoid appearing ridiculous" can, therefore, exclude some of the above-mentioned lexicographic data, it will still be very difficult to incorporate the rest of the relevant data in an $\mathrm{L}_{1}-\mathrm{L}_{2}$ word list. And not only that: as full equivalence between the words of two languages is rather the exception than the rule, the lexicographer would necessarily have to address two or more $\mathrm{L}_{2}$ equivalents to quite a number of $\mathrm{L}_{1}$ lemmata. If the above-mentioned data - even in a reduced version - were to be attached to each and every of these equivalents, it would lead to a heavily loaded dictionary article and a very complex and surely 
not very user-friendly article structure. Furthermore, many $\mathrm{L}_{2}$ translation equivalents of $L_{1}$ collocations would not contain the $L_{2}$ equivalents addressed to the lemma. This would require that much additional data should also be attached to all these collocations. And the same applies even more to idioms and proverbs as well as to synonyms, antonyms, hyponyms etc. One such example is the Danish spis brød til (literally: "eat bread at the same time"), which means something like "take it easy" or "calm down" in English. It would not be easy to include any further information on "take" and "calm" under the lemma spise (eat) in a Danish-English dictionary or to make references to another Danish lemma where users could find the needed information about the English word.

Hence, it can be concluded that an $\mathrm{L}_{1}-\mathrm{L}_{2}$ word list is not the most suitable aid to provide assistance with foreign-language text production. Of course, if one, as Shcherba, accepts the production of $\mathrm{L}_{2}$ texts "without gross mistakes", i.e. with some mistakes, a word list of the above scope would be capable of supporting the production of texts in a foreign language. But apart from leading to some mistakes, it would also allow some degree of mixed bilingualism in terms of language assimilation. It is, therefore, evident that lexicography should search for another solution to the problem. And this solution can actually be found in lexicographic practice itself. Many dictionaries for a great number languages include a special list of verbs or even a second bilingual word list and provide, by means of an advanced distribution structure, data addressed to a specific lemma or an equivalent in other component parts of the dictionary. The following examples are from one such dictionary:

comer [E1] vi (a) (en general) to eat; no tengo ganas de

$\sim$ I'm not hungry...

Example 1: Dictionary article from Spanish-English word list in Oxford (2000)

eat $/ \mathrm{i}: \mathrm{t} /$ (past ate; past $p$ eaten) $v t / i$ comer...

Example 2: Dictionary article from English-Spanish word list in Oxford (2000)

$\begin{array}{lll}\text { infinitive/ } & \text { past tense/ } & \text { past participle/ } \\ \text { infinitive } & \text { pretérito } & \text { participio pasado } \\ \ldots . & \ldots & \ldots \\ \text { dwell } & \text { dwelt, dwelled } & \text { dwelt, dwelled } \\ \text { eat } & \text { ate } & \text { eaten } \\ \text { fall } & \text { fell } & \text { fallen } \\ \ldots & \ldots & \ldots\end{array}$

Example 3: Excerpts from verb list in Oxford (2000)

If Spanish-speaking users, in the context of English text production, need information on the inflection of an English verb, what then is the role of the $\mathrm{L}_{1}-$ $\mathrm{L}_{2}$ word list in the above-mentioned dictionary? It clearly serves as an index or 
a "bridge" to the place (verb or word list) where the relevant data can be found. The $\mathrm{L}_{1}-\mathrm{L}_{2}$ word list barely functions as part of the outer access structure guiding the user first to the word list and then to the article where these data are placed according to the distribution structure chosen for the dictionary. In this specific case, it has no other function. Other dictionaries might, apart from the $\mathrm{L}_{1}-\mathrm{L}_{2}$ word list, only incorporate an $\mathrm{L}_{2}$ or $\mathrm{L}_{2}-\mathrm{L}_{1}$ word list where data on inflectional morphology could be found, whereas others might only have a specific verb list of the above type. This is, for instance, the case with many dictionaries of Spanish where there are up to 58 relevant forms of a verb to be treated, something which is rather complicated to incorporate in a normal dictionary article. But what exactly is a list of verbs or irregular verbs? In the lexicographic literature, it is often referred to as back matter. But if it is analysed according to lexicographic principles, it is, in fact, a word list just as any other such list. It is the result of a selection based on a set of principles (being verbs or irregular verbs); it has an alphabetic macrostructure as most lexicographic word lists and a well-defined microstructure although this may vary from that of other types of word lists. If a reference work only consisted of one such list of verbs, it would therefore necessarily have to be typologised as a dictionary, i.e. a dictionary made for a special purpose.

This experience can be generalised: When users need a specific type of information about $\mathrm{L}_{2}$ in order to solve a specific type of problem related to a specific type of user situation, and when they might not know the $\mathrm{L}_{2}$ lemma where they can find this information, the data providing this information can be addressed to the lemmata of an $\mathrm{L}_{2}$ word list and an $\mathrm{L}_{1}-\mathrm{L}_{2}$ index can then serve as a bridge giving access to these data. But how should such an $\mathrm{L}_{1}-\mathrm{L}_{2}$ index or bridge be designed?

The answer to this question once more depends on the methodology applied by users in the foreign-language learning process. If the contrastive method is used, the $\mathrm{L}_{1}-\mathrm{L}_{2}$ index should actually be a traditional $\mathrm{L}_{1}-\mathrm{L}_{2}$ word list where additional data have been placed in an $\mathrm{L}_{2}$ list. However, if this method is not being used and the compiler of the dictionary tries to avoid any contribution to a mixed bilingualism, then there are two options. One is to try to combine Shcherba's vision of a "special type of dictionary" with the above considerations and the other is to conceive a completely new set of principles for such an index.

The problem here is evidently that Shcherba himself never developed his proposal in the necessary detail. However, in one of his writings on lexicography, Shcherba formulated five general principles for a Russian-French "special type of dictionary" designed for Russian users. Mikkelsen (1992: 27) summarises these principles as follows:

1. Provide a translation, not an explanation, that will, in the appropriate grammatical form, fit into a correct French sentence which has been translated from a Russian sentence. Of all candidates choose the one which fits into most of the 
Russian contexts. If no general equivalent is found, make sure that the intended user has enough information to judge which one will serve him best.

2. Reject the translations which are "too French" and metaphorical, and take only the simplest ones in order not to let the user seem ridiculous.

3. Throw away all approximate translations and synonyms - again in order not to make anecdotal translations possible.

4. If no precise equivalent is available, give the approximate ones together with the corresponding explanations. If not even an approximate equivalent can be found, leave the lemma as untranslatable, followed by an explanation in brackects. Under certain circumstances bring a translation of whole contexts.

5. Provide the necessary grammatical information, so that the user can produce the correct morphological and syntactic forms.

The first four points are interesting although it is evident that they would lead to a very simple foreign-language text without much stylistic variation and, as such, suitable only for a beginner's level (what exactly was Shcherba's idea). It is, however, the fifth point that presents the biggest problems. Firstly, it is not clear what exactly is meant by the "necessary grammatical information"? What kind of morphological and, especially, syntactic information does it include? Are collocations, for instance, part of this information? Secondly, as it has been argued above, data providing this kind of information are exactly of the type that is difficult to incorporate in an $\mathrm{L}_{1}-\mathrm{L}_{2}$ word list. Hence, although they include innovative ideas, there is no clear-cut and definitive solution to be found in Shcherba's lexicographic reflections.

The conclusion is therefore that a completely new set of principles for an $\mathrm{L}_{1}-\mathrm{L}_{2}$ index to an $\mathrm{L}_{2}$ word list has to be developed. Such a set of principles could be as follows:

(a) A list of $\mathrm{L}_{1}$ words is selected.

(b) Data providing information on part of speech is addressed to these words (for some languages also information on gender). This is done in order to help the user to be assured that he/she has arrived at the right word.

(c) $\mathrm{L}_{2}$ equivalents are addressed to all $\mathrm{L}_{1}$ words. These $\mathrm{L}_{2}$ equivalents, at the same time, make up implicit references to the corresponding lemma in the $\mathrm{L}_{2}$ word list.

(d) If several $\mathrm{L}_{2}$ equivalents are addressed to the same $\mathrm{L}_{1}$ word, then meaning differentiation is provided. This is done in order to help the user to select the right $\mathrm{L}_{2}$ word.

(e) No more data is addressed to the $\mathrm{L}_{2}$ equivalents. This is done in order to force the user to proceed directly to the $\mathrm{L}_{2}$ word list.

(f) $\quad \mathrm{L}_{1}$ idioms are selected and attached to the corresponding $\mathrm{L}_{1}$ words.

(g) An $\mathrm{L}_{2}$ translation equivalent is addressed to each $\mathrm{L}_{1}$ idiom together with the $\mathrm{L}_{2}$ lemma where further information about this equivalent can be found. This is done because the $\mathrm{L}_{2}$ translation of an $\mathrm{L}_{1}$ idiom does not 
necessarily contain one of the other equivalents addressed to the corresponding $L_{1}$ word and in order to permit the user to proceed directly to the $\mathrm{L}_{2}$ word where further information is to be found.

As can be seen, an $\mathrm{L}_{1}-\mathrm{L}_{2}$ index based on these seven principles contains very few data and, thus, provides little information on $\mathrm{L}_{2}$. Although it can be used as a "reminder" for those users who already know and manage the $\mathrm{L}_{2}$ word, but have just forgotten it, in most cases it would force users to proceed to the $\mathrm{L}_{2}$ word list in order to find the information needed. In this way, the above proposal reduces the danger of a "mixed bilingualism" to a minimum. Of course, no guarantee can be given, as even the best dictionary is never immune to improper use. But this is mainly a question of dictionary culture.

\subsection{Proposals for an $\mathrm{L}_{2}$ word list}

How should the $\mathrm{L}_{2}$ word list of an $\mathrm{L}_{2}$ text production dictionary be conceived? What kind of lexicographic data should it contain? In order to answer this question, it must be stated that the basic principle of dictionary conception always is - or should be - that no data is included because of "tradition" or the practice of existing dictionaries. It is not a question of what users expect to find in the dictionary due to an improper lexicographic culture, but what they actually need. The user-friendliness of a dictionary can be analysed in two different and, frequently, contradicting ways. The compiler of the dictionary can, for instance, observe how a hundred persons are using his dictionary and what problems they may have in using it. He can then develop a new model that is easier to consult, i.e. more user-friendly in terms of its use. But he can also consider how the dictionary functions, how it helps users and contributes to their needs, and then develop a new type of dictionary which is more helpful and fulfils the needs of the users even better than the old one, i.e. is more userfriendly in terms of its effect. Of course, in this last case, it might be necessary to "re-educate" users and teach them how to use the new dictionary properly. Users' real needs should therefore always be put in the centre of dictionary conception and planning. Each and every type of data included in the $\mathrm{L}_{2}$ word list should be argued on the basis of the function of the dictionary, i.e. to assist users in solving problems related to foreign-language text production.

Mugdan (1992a) argues that the optimal lexicographic tool to assist users in foreign-language text production is a monolingual $\mathrm{L}_{2}$ dictionary, but that a bilingual $\mathrm{L}_{2}-\mathrm{L}_{1}$ dictionary, for the benefit of its users, could also be designed to provide for this function, a solution rather close to Shcherba's "explanatory dictionary". In this vein, Mugdan proposes that the $\mathrm{L}_{2}$ "free production" dictionary - apart from orthographic, phonological and semantic data - should contain information on inflection and syntax and several examples of how to use the words. This proposal, however, has to be concretised and other types of data added. But first, it should be stated that any well-designed dictionary nec- 
essarily contains two different types of lexicographic data with totally different functions: the data intended to cover the users' primary needs, i.e. to solve their needs in a specific user situation, and the data intended to satisfy the users' secondary needs, i.e. to solve the problems related to the use of the dictionary (Tarp 2000). On this basis, the following proposal is presented, including apart from the lemma - data on part of speech, gender, orthography, pronunciation, meaning, pragmatic and cultural notes, inflection, combining forms, syntactic properties, collocations, idioms, proverbs, stereotype phrases, text examples, synonyms, antonyms, hyponyms etc.

Part of speech. This item has two functions. Firstly, it is a means of identification - at least for the languages where the same grapheme might represent words with different parts of speech - in order to assure users that they have arrived at the right word. In this sense it covers the secondary user needs. Secondly, it provides some basic or general information on semantics, the inflectional paradigm and syntactic properties, i.e. primary user needs necessary for the purpose of text production.

Gender. This item might also have two functions: to identify the right word, at least in languages with two or more genders, and to provide basic information on the inflectional paradigm and some general indications of the syntactic properties of the word.

Orthography. This type of data is included both to confirm the arrival at the right word and to provide indications for written text production in the foreign language. Data on orthography are normally furnished implicitly through the lemma form and the inflectional paradigm. But if there are two or more competing orthographic forms of a given word, these should all be indicated in order to avoid any confusion whether or not the user has found the right word.

Pronunciation. This type of data also has two functions, i.e. to confirm that the user has found the right word and to provide indications for oral text production in the foreign language.

Meaning. In a production dictionary, data on meaning are exclusively provided with the purpose of confirming to users that they are about to use the right word. Users are already supposed to have an idea of what they want to express, i.e. they already know the meaning and just need to put words to it. As such, it is evident that the dictionary should expose all the different meanings and senses of the word in order to satisfy the users' needs in any user situation. The meaning of the $\mathrm{L}_{2}$ words can be given in at least four different ways: $\mathrm{L}_{2}$ explanations, $\mathrm{L}_{1}$ explanations, $\mathrm{L}_{1}$ equivalents and illustrations. Which of these ways are the most convenient will be discussed in section 6 .

Pragmatic and cultural notes. Pragmatic notes are necessary in order to avoid users applying certain words out of context. And cultural notes are likewise necessary in order to avoid possible misunderstandings. The equivalent in Fang (a Gabonese language) of the English word wedding is, for example, àluk, but whereas wedding for most members of the English-speaking community 
refers to a contract between two persons, for most native Fang speakers àluk would refer to a contract between two families. This type of cultural information should, of course, be available in the dictionary.

Inflection. All data about inflection are exclusively provided in order to serve the primary user needs, i.e. to assist text production. The inflectional paradigm might be incorporated directly in the $\mathrm{L}_{2}$ article which often is the case in languages with a relatively reduced number of inflectional forms such as English, Danish and Afrikaans, or it can be placed in a separate verb list, which is frequently the case with languages with a considerable number of inflectional forms, such as Italian verbs or Icelandic nouns. In order to save space, the regular inflectional paradigms might be omitted in the individual dictionary articles and implicit or explicit references made to the outside matter of the dictionary where the regular inflectional paradigm is exposed in a special section. But the explicit incorporation, in one way or the other, of all irregular and even infrequent inflectional paradigms should be compulsory in any dictionary for text production.

Combining forms. It is evident that knowledge about word formation, especially affixes and compound words, is crucial in order to create a text in a foreign language. For languages, such as Spanish and Afrikaans, with a tradition of adding diminutives, augmentatives and other affixes to the nucleus word, this should, of course, be reflected in a production dictionary. In a similar way, for languages with many compound words, such as Danish, Afrikaans and German, it is important to furnish data on the building properties of each word and illustrate it with some examples. A classical example is the Danish word barn (child) which, apart from a totally obsolete genitive form (e), is combined both with its singular and plural forms (barn and børn) in a quite unpredictable way: barnepige (babysitter), barnevogn (perambulator), børnetøj (children's cloth), børnehave (kindergarten) etc. No foreign-language learner would be able to construct these and similar compound words in Danish without the corresponding lexicographic data.

Syntactic properties. This aspect is often ignored or very badly treated in dictionaries (and in lexicographic literature in general). Information on the syntactic properties of a given word is, however, even more necessary than word formation in order to create phrases in the foreign language. The syntactic properties should, therefore, be indicated for all the relevant words, and this should be done in an explicit way and not, as is the case with most dictionaries that supply such data, implicitly through a number of text examples. Such text examples are, of course, important in order to illustrate or even complement the explicit indications, but they should never stand alone because this requires that users themselves must be capable of generalising from the specific example to the general rule, something which might be difficult and sometimes not even possible. For instance, in a dictionary designed to assist foreign-language speakers in text production in English, it should be explained explicitly that the verb tell might, at least, be combined syntactically in the following ways: 
— tell something

- tell somebody something

- tell somebody (that) + clause

- tell somebody to + infinitive

- tell somebody what/how to + infinitive

Each of these explicit indications could then be followed by a number of text examples and not, as in Cambridge (1996), the other way round. The syntactic indications should, however, never be presented in such an abstract and complex way, as is the case in De Gruyter (1999):

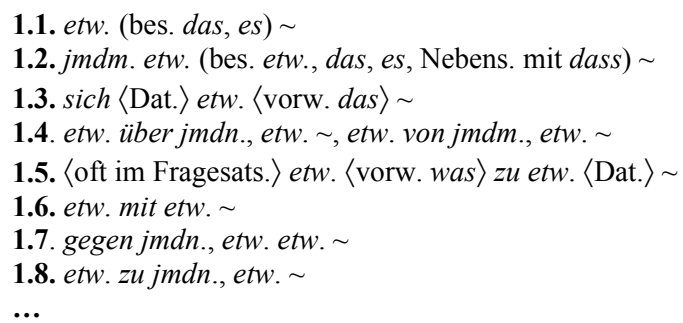

Example 4: Excerpts from dictionary article in De Gruyter (1999)

The above minirules might, indeed, only be understood by linguists or people with a certain degree of linguistic training. The "normal" learner would most certainly get lost in this highly condensed and codified language. This article is, however, not the right place to give a detailed treatment of the very complex question of syntax in production dictionaries.

Collocations and idioms. Collocations constitute an important part of the specific syntactic properties of many words, but are often quite unpredictable. The way the Danish word bil (car) collocates with the word kore (drive) is, for example, not the same as in English and Spanish. Whereas the English and Spanish equivalents of the Danish collocation krre bil are drive a car and conducir a coche, the corresponding equivalents of the collocation køre $i$ bil are go by car and ir en coche, i.e. with another verb. The English and Danish equivalents of the Spanish lavar los dientes (literally: wash the teeth) are brush one's teeth and borste tænder and so on. As even these frequent and daily used collocations are unpredictable, any good dictionary for text production should provide such collocations.

According to linguistic theory, collocations are characterised by transparency, but practice nevertheless shows that foreign-language speakers frequently have difficulties in understanding them, which means that an explanation or equivalent in the users' native language should be furnished. More or less the same applies to idioms that also constitute a considerable part of a given language. Hence, the most common idioms should also be included in a production dictionary. Although many linguist theories have been developed in order 
to distinguish between idioms and collocations, most users do not know how to establish this distinction and would waste unnecessary time if idioms and collocations were placed in different sections or fields of the dictionary article. Even though many linguists may protest, because of user-friendliness, collocations and idioms should therefore be treated in the same way and at the same place in a dictionary for $\mathrm{L}_{2}$ text production.

Proverbs. Although it is quite possible to make oneself understood without the use of proverbs, it should nevertheless be recommended that such word combinations are incorporated in text-production dictionaries, at least if they are conceived for more advanced foreign-language speakers. And they should be clearly explained or a mother-tongue equivalent should be given.

Stereotype phrases. A number of stereotype phrases used in specific contexts such as How are you?, Have a nice weekend, Give my love to Jane, etc., should also be included in the dictionary and explained.

Text examples. Many lexicographers — like Mugdan (1992a) — argue that text examples should be provided in dictionaries in order to illustrate how the words are used in concrete contexts. This argument is both reasonable and important, but the text examples should not be isolated from the other data included in the dictionary article and placed in a separate section or field. Quite the opposite, they should - as is practice in a number of dictionaries - be integrated with these data and placed in direct connection with them in order to show how they could be used in a concrete context. They could, for example, be placed after each syntactic "minirule" in order to expose this rule in a more concrete way. And they could also - especially in electronic dictionaries where space is not a problem - be presented in such a way that they illustrate the use of collocations and idioms.

Synonyms, antonyms, hyponyms etc. The only purpose of including synonyms, antonyms, hyponyms and similar words in a dictionary for text production is to assist users in producing text with a more varied vocabulary. Synonymy is not only interesting at word level but also for collocations, idioms and phrases as suggested by Jónsson (1999). If there is not complete synonymy or antonymy, items of meaning differentiation should be added in order to help users to select the right word in any context. As all the relevant morphological and syntactic data cannot be provided in the dictionary article where they are indicated as synonyms, antonyms or hyponyms, all such words should also be selected as lemmata, to which users can be referred for more information.

The above proposal about information categories in dictionaries for foreign-language text production is, of course, not the last word to be said in this regard. Everything has to be worked out in a far more detailed way and adopted to each set of languages and different categories of users. In this regard, it is evident that more or less data of the above-mentioned types could be included in the dictionary depending on the $\mathrm{L}_{2}$ level of the user group. Other types of data might also be included, especially for more advanced users. But 
in general, these are the most important lines along which a new generation of dictionaries for $\mathrm{L}_{2}$ text production should be conceived.

\section{Integration with foreign-language reception}

It is rather expensive and inconvenient to make dictionaries designed for only one function. This might be possible for languages with a large number of speakers, like English, but for "smaller" languages it would be financially more feasible for publishing houses to produce multifunctional dictionaries. And for users, it would clearly also be more convenient if the same dictionary could be consulted in order to solve problems related to more than one user situation. As will be seen in the following, it is fairly easy to combine foreign-language text production with foreign-language text reception within the framework of one and the same dictionary. Actually, a well-conceived production dictionary already contains most of the data necessary to satisfy users' needs in terms of text reception. Only a few additional data need be included in the dictionary in order to serve this function and these should in no way disturb the general structure and user-friendliness of the dictionary. But what data are needed to assist users in foreign-language text reception?

In order to answer this question, it should be remembered that lexicographic data may have two completely different functions: Firstly, they may cover the primary user needs, in this case assistance with text reception, and, secondly, they may satisfy the secondary user needs, i.e. guiding the user to the lemma where this assistance is given and helping to confirm that the lemma is actually the right one.

In real texts, foreign-language readers or listeners may find irregular, rare or even "surprising" inflectional forms they neither understand nor are able to relate to the basic form lemmatised. In English, for instance, this would be "old" plural forms such as teeth (tooth), geese (goose) and feet (foot) and irregular past tenses of verbs like ate which is even to be found under quite another letter than the infinitive form eat. In Afrikaans, it would include irregular past tenses such as was (wees: be), sou (sal: shall), wou (wil: will), kon (kan: can) and moes (moet: must), "strange" plural forms of nouns like skepe (skip: ship) and stede (stad: city) which a learner, at least at the beginner's level, would not be expected to know.

As foreign-language speakers are not supposed to know all these inflectional forms and might have problems understanding them, it is evident that, in a dictionary for text reception, these irregular or strange forms should be selected as lemmata from where a reference could be made to the lemmatised form, for example the infinitive or singular form, where all the relevant data are to be found. The same applies to orthographic variants. The Spanish noun yerba (grass), which can still be found in a large number of texts, is, for example, a variant of the more frequent hierba. Few foreign-language speakers that have not come across these forms before would be able to relate these two orthographic variants that are placed far from each other in any alphabetic 
organised dictionary. Both variants should, therefore, be selected for a textreception dictionary, and the less frequent one could then be given the status of a reference lemma referring users to the other variant where the relevant data are provided.

Once users have found the lemma they have been looking for, another type of secondary user needs occurs as they need confirmation that the lemma is actually the right one. This confirmation is, first of all, furnished through orthographic and/or pronunciation data (for written and/or oral text reception). But as users might have come across an inflectional form or orthographic variant, they also need confirmation that these are actually included in the lemma in question and this is, once more, done by incorporating the relevant data in the dictionary article. However, as have been suggested in section 5, the inclusion of these same data has already been done for the purpose of text production. Hence, as regards the secondary user needs, the only data to be added to the dictionary in order to enhance it from an $\mathrm{L}_{2}$ production dictionary to an $\mathrm{L}_{2}$ production and $\mathrm{L}_{2}$ reception dictionary are a number of reference lemmata whose inclusion disturbs neither the general structure nor the content of the dictionary.

As regards the primary user needs, it is evident that a dictionary for $\mathrm{L}_{2}$ text production cannot provide understanding of whole texts as such. It can only provide assistance to understanding at word, collocation, idiom and proverb level as well as to finding the meaning of some stereotype phrases. In section 5, it has already been argued that the meaning of collocations, idioms, proverbs and stereotype phrases should be provided in a dictionary for $\mathrm{L}_{2}$ text production. Hence, this kind of data would already have been included in a production dictionary and might therefore also serve the purpose of text reception.

The remaining question now is how to explain the meaning of the lemmata. In section 5 it was mentioned that data on meaning could be provided in at least four different ways, i.e., by means of $\mathrm{L}_{2}$ explanations, $\mathrm{L}_{1}$ explanations, $\mathrm{L}_{1}$ equivalents and illustrations, or as a combination of these. $\mathrm{L}_{2}$ explanations are actually provided in many monolingual learner's dictionaries, for example the English Big Five (Oxford, Cambridge, Longman, Cobuild and Macmillan), the German De Gruyter, Langenscheidt and Grundwortschatz, the Spanish Vox, the Swedish Lexin, the Afrikaans Basiswoordeboek and so on. However, none of these dictionaries are conceived for users of a specific language community, so the decision whether or not to choose $\mathrm{L}_{1}$ explanations or equivalents was probably never considered. Nevertheless, all the above-mentioned dictionaries pose one big problem: How to understand the explanations?

handicraft $[\ldots]$ (a) an activity such as sewing or weaving, done with one's hands and requiring artistic skills: handicraft classes. (b) items made in this way: a sale of handicraft(s).

Example 5: Dictionary article from Oxford (1998) 
Panzer [...] auf Raupen (2) laufendes, vollständig mit Platten aus Stahl versehenes, geschlossenes und bewaffnetes Fahrzeug für den militärischen Kampf

Example 6: Dictionary article from De Gruyter

hoek $[\ldots]$ (1) 'n Hoek van iets is 'n punt of 'n gebied waar twee of meer van sy kante, lyne of vlakke bymekaar kom. Dit kan ook die gebied of ruimte wees naby die plek waar die twee of drie kante of vlakke bymekaar kom [...] (2) 'n Hoek kan die afstand of ruimte wees tussen twee lyne of kante by die punt waar hulle aan mekaar raak [...] (3) 'n Hoek is 'n gebuigde stuk metaal wat gebruik word om iets, veral vis, mee te vang: vishoek.

Example 7: Dictionary article from Basiswoordeboek

It goes without saying that users of Oxford should not only have reached a certain level of mastery of the English language but should also have a relatively developed capacity for generalisation should they be able to understand the above explanation and grasp the full meaning of the word. De Gruyter uses several difficult words and an unnecessarily complex syntax in order to explain a word representing something that everybody knows and that could be far more easily explained by an illustration. Basiswoordeboek uses a simple and rather stereotype definition language but even so it is still evident that a certain level of Afrikaans is needed in order to understand the explanations. Some of the dictionaries mentioned above, for example the English Cambridge, Longman and Macmillan and the Spanish Vox, have selected a reduced vocabulary of 2000 or 2500 words for their explanations whereas Oxford has a slightly bigger defining vocabulary of 3500 words.

outreach $[\ldots]$ relating to efforts to bring government and a range of social services to people where they live or spend time * an outreach worker * AIDS outreach programs bring medical care, condoms and counselling to prostitutes on the streets.

Example 8: Dictionary article from Cambridge

trepar $[\ldots] 1$ intr. Subir a un lugar alto y difícil ayudándose de los pies y de las manos: los niños treparon al árbol más alto; treparon por la pared y saltaron al otro lado; el gato trepó hasta la copa del manzano. $\Rightarrow$ encaramar. 2 Crecer ciertas plantas subiendo y sujetándose a los troncos y ramas de los árboles, a las varas y a otros objetos: la yedra trepaba por la tapia; puso unas cañas para que trepara la vid. 3 fam. Con- 
seguir un puesto importante o una posición social alta usando todos los medios posibles: ha amasado su fortuna trepando y adulando a los demás.

Example 9: Dictionary article from Vox

This reduced vocabulary, of course, makes it much easier, but it still does not solve the problem for users at the very beginner's levels. It does not solve the problems where a certain capacity for generalisation is needed in order to grasp the full extent of an explanation. And, at the same time, it is really a question if all the explanations are indeed unequivocal.

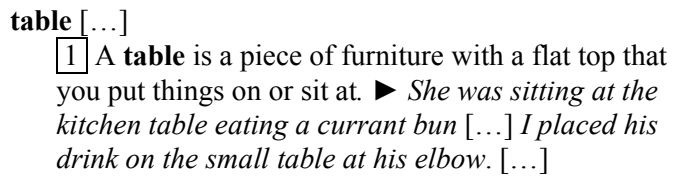

Example 10: Dictionary article from Cobuild

This explanation could be interpreted in various ways. Of course, the additional text examples also help to get the right understanding of the word. But why complicate matters for users who just need a quick answer? Why not add something as simple as an illustration to the lemma as has been done in Longman, Cambridge Macmillan, Oxford and the German Grundwortschatz. There are actually quite a number of words that could be better explained in this way, for example chair, door, cat, dog, hand, foot etc. An illustration referring to a reality already known by users would in most cases be the best way to explain the lemma. However, in other cases - such as wonder, reconsider, feel, confirm, interpret, etc. - an illustration would hardly be able to expose the true meaning of a word and, even less, its various senses. In such cases, which probably make up the big majority, language is necessary in order express the meaning. It is, nevertheless, a question if an explanation in the foreign language would always be enough to enable users to grasp the exact meaning of the word in question. Beginners would definitely have problems, but even more experienced users would, at least sometimes, have doubts whether or not they have understood it right. Advanced users would, of course, have fewer problems but if lexicographers want to make a dictionary designed for users with different levels of mastery of the foreign language, they have to look for other solutions.

As already mentioned in section 2, Shcherba (1940) proposes a model for a "foreign defining dictionary" where the explanations are provided in the users' native language and equivalents only accepted in those cases "when this would simplify definition and would not be detrimental to a full understanding of the foreign word's true nature" (Shcherba 1940: 341). This solution is a tempting one and deserves much more attention.

Shcherba's mission was to produce a dictionary assisting with the assimilation of the foreign-language system, i.e. lexis and grammar, but there is little 
doubt that this function - in Shcherba's concept - up to a certain degree is interwoven with $\mathrm{L}_{2}$ text reception, as the dictionary was conceived as a consultation dictionary and not a "reading dictionary" according to the classification made by Hausmann (1977). Some of the most valuable comments on Shcherba's proposal, at least outside Russia, have been put forward by Duda (1986) and Duda et al. (1986). They were preparing a so-called "active" RussianGerman dictionary for German users and, in this connection, they resumed the criticism directed against another Russian-German dictionary, made by Bielefeldt, where the latter had used Shcherba's principles for a "defining dictionary". According to them, Shcherba's idea of providing explanations of the meanings of foreign words in the users' mother tongue had proved problematic in practice (Duda 1986: 13. Translated by ST):

The user is, apparently, capable of fulfilling the analysis of the word's meaning as it is described in a monolingual dictionary. But it seems to be far more difficult for him to name the meaning on the basis of a given description, i.e. to proceed to the lexicalisation.

On this basis, Duda (1986) concludes that Shcherba's principle of giving priority to the explanation should be changed and that priority should be given to the equivalent whenever this is possible and sufficient. According to Duda, this would not change the foundations of Shcherba's ideas. The above argumentation does not seem to give Shcherba justice. If users understand the meaning of a word, nothing more is required from a dictionary whose purpose is to assist them in foreign-language assimilation and text reception. The lexicalisation into the users' native language is, in fact, only necessary when the function of the dictionary is to assist the translation of foreign-language texts into this language. Duda (1986) and Duda et al. (1986) also criticize the fact that explanations and equivalents are not separated and claim that this could create problems for users. But as the following example shows, there are cases where the simultaneous provision of both an equivalent and an explanation is the best solution:

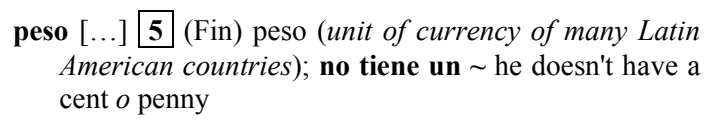

Example 11: Dictionary article from Oxford (2000)

The comments by Duda (1986) and Duda et al. (1986) are, nevertheless, highly valuable and should be taken into consideration in the future development of lexicographic theory. There is, for instance, no doubt that a cumulative selection of equivalents in the users' mother tongue in many cases would be sufficient in a dictionary designed for foreign-language text reception. With such a cumulative selection users would be able to pick up exactly that equivalent which provides meaning to a word within a concrete context. In this regard, it does not constitute any problem that a word chosen as an equivalent also might 
have an additional sphere of meanings and senses not included in the lemma. When the user situation to be assisted is the assimilation of the foreign-language lexis, this might perhaps create a wrong idea about the real meaning of the foreign word. But would it necessarily do this? It goes without saying that a dictionary conceived for $\mathrm{L}_{2}$ text reception should avoid contributing to any form of "mixed bilingualism" and, therefore, harm the overall language-learning process. This is, however, not the topic of this article and should be left to future theoretical discussions.

For the purpose of this article it suffices to conclude that whatever method is used to explain the lemma for the sake of foreign-language text reception is also sufficient for the sake of foreign-language text production. Although it might frequently be necessary to provide more extensive data for the purpose of text reception, these data will in no way conflict with the data needed for text production as the latter constitute a genuine subset of the former.

To summarise this section: The above discussion has indicated that the additional data - in terms of reference lemmata and explanations - needed to adapt a foreign-language production dictionary to the purpose of foreign-language text reception, will in no way disturb its character as a production dictionary. On the other hand, whether or not the data included in the dictionary for the purpose of production and irrelevant for the purpose of reception will reduce its usefulness as a reception dictionary, will primarily depend on the internal distribution structure in the dictionary article and the corresponding search-field structure. Users who only need assistance with text reception should, of course, be able to proceed directly to the relevant data without passing through a lot of irrelevant, time-consuming data. This, however, is only a question of knowing the problems and choosing the most appropriate structures.

\section{Conclusions}

The overall method used in this article was first to analyse and describe the dictionary functions and then to discuss the relevant categories of lexicographic data. This is the opposite method of the one used in most theoretical works about lexicography, for example Herbst (1999) and Zöfgen (1994), where the lexicographic data is discussed without any relation to specific functions. The former method points to a science-based lexicographic theory while the latter leads to a kind a theory that hardly can provide the necessary guidelines for the future high-quality dictionaries that modern society needs.

Through the combined methods of analysis-synthesis and inductiondeduction, this article has taken some fundamental steps towards a general theory of dictionaries, whether printed or electronic, designed to assist the users in foreign-language text production and reception. It is evident that there are still important questions to be dealt with, such as the users' specific needs at different levels of foreign-language mastery, how to expose the syntactic prop- 
erties, what are the benefits of the different ways of explaining the words and how to structure the lexicographic data in correspondence with the specific user needs. It is also evident that some of the categories treated in this article, up to a certain point, are language-specific and that others might be added for other languages, especially outside the Indo-European language family.

Another important question is to develop a method through which monolingual foreign-language production and reception dictionaries can be given a bilingual dimension. This is what has been done with the Swedish Lexin which, in spite of a highly codified and difficult metalanguage, is probably one of the most interesting learner's dictionaries in the world. This dictionary was originally conceived as a monolingual learner's dictionary for foreign immigrants in Sweden and then it was "translated" and specifically adopted to the needs of several of the most important emigrant languages in Sweden (see Gellerstam 1999). The generalisation of this idea would not only make it much easier and cheaper to produce dictionaries adapted to the specific language speakers' specific needs, but would, as such, also point to a much higher quality product than the actual monolingual dictionaries for foreign-language speakers in general.

\section{Literature}

\section{Dictionaries}

Basiswoordeboek 1994 = Gouws, Rufus, Ilse Feinauer and Fritz Ponelis. 1994. Basiswoordeboek van Afrikaans. Pretoria: J.L. van Schaik.

Cambridge 1996 = Procter, Paul (Ed.). 1996. Cambridge International Dictionary of English. Cambridge: Cambridge University Press.

Cobuild 2001 = Sinclair, John (Ed.). 2001. English Dictionary for Advanced Learners. London: HarperCollins.

Dansk grundordbog 1994 = Dollerup, Cay and Inge Padkær Nielsen. 1994. Dansk grundordbog . Genvej til det danske sprog. Copenhagen: Høst \& Søn.

De Gruyter 2000 = Kempcke, Günter (Ed.). 2000. De Gruyter Wörterbuch Deutsch als Fremdsprache. Berlin/New York: Walter de Gruyter.

Grundwortschatz 1983 = István, Kosasras. 1983. Grundwortschatz der deutschen Sprache. Berlin: Volk und Wissen Volkseigener Verlag.

Langenscheidt 1993 = Götz, Dieter, Günther Haensch and Hans Wellmann (Eds.). In collaboration with Vincent J. Dochertz and Günther Jehle. 1993. Langenscheidts Großwörterbuch Deutsch als Fremdsprache. Das neue einsprachige Wörterbuch für Deutschlernende. Berlin/Munich: Langenscheidt.

Lexin 1993 = Gellerstam, Martin (Ed.). 1993. Lexin. Språklexikon för invandrare. Svenska ord - med uttal och förklaringar. Uppsala: Norstedts Förlag.

Longman 1995 = Summers, Della. 1995. Longman Dictionary of Contemporary English. Harlow: Longman.

Macmillan 2002 = Rundell, Michael (Ed.). 2002. English Dictionary for Advanced Learners. London: Macmillan. 
Oxford 2000 = Carvajal, C.S. and J. Horwood (Eds.). 2000. The Pocket Oxford Spanish Dictionary. Spanish-English English-Spanish. Oxford: Oxford University Press.

Oxford 1998 = Crowther, Jonathan (Ed.). 1998. Oxford Advanced Learner's Dictionary. Oxford: Oxford University Press.

Vox 1995 = 1995. VOX Diccionario para la enseñanza de la lengua española. Alcalá de Henares/Barcelona: Universidad de Alcalá de Henares/Biblograf.

\section{Theoretical contributions}

Bergenholtz, Henning and Sven Tarp. 2002. Die moderne lexikographische Funktionslehre. Diskussionsbeitrag zu neuen und alten Paradigmen, die Wörterbücher als Gebrauchsgegenstände verstehen. Lexicographica 18: 253-263.

Bergenholtz, Henning and Sven Tarp. 2003. Two Opposing Theories: On H.E. Wiegand's Recent Discovery of Lexicographic Functions. Hermes, Journal of Linguistics 31: 171-196.

Bergenholtz, Henning and Sven Tarp. 2004a. The Concept of "Dictionary Usage". Dollerup, Cai (Ed.). Worlds of Words. A Tribute to Arne Zettersten. Nordic Journal of English Studies 3(1): 23-36, 2004.

Bergenholtz, Henning and Sven Tarp. 2004b. Wörterbuchfunktionen. Barz, Irmhild, Henning Bergenholtz and Jarmo Korhonen (Eds.). 2004. (Lerner-)Lexikografie: Ein- und zweisprachig für Deutsch und Finnisch. Frankfurt am Main/Bern/New York/Paris: Peter Lang.

Duda, Walter. 1986. Ein «aktives» russisch-deutsches Wörterbuch für deutschsprachige Benutzer? Günther, Erika (Ed.). 1986. Beiträge zur Lexikographie slawischer Sprachen: 9-15. Linguistische Studien. Reihe A. Arbeitsberichte. Akademie der Wissenschaften der DDR. Zentralinstitut für Sprachwissenschaft 147. Berlin: Akademieverlag.

Duda, W., M. Frenzel, E. Wöller and T. Zimmermann. 1986. Zu einer Theorie der zweisprachigen Lexikographie. Überlegungen zu einen neuen russisch-deutschen Wörterbuch. Linguistische Studien. Reihe A. Arbeitsberichte. Akademie der Wissenschaften der DDR. Zentralinstitut für Sprachwissenschaft 142. Berlin: Akademieverlag.

Gellerstam, Martin. 1999. LEXIN — lexikon för invandrare. LexicoNordica 6: 3-18.

Hausmann, Franz Josef. 1977. Einführung in die Benutzung der neufranzösischen Wörterbücher. Tübingen: Max Niemeyer.

Herbst, Thomas and Kerstin Popp (Eds.). 1999. The Perfect Learners' Dictionary (?). Lexicographica. Series Maior 95. Tübingen: Max Niemeyer.

Jónsson, Jón Hilmar. 1999. Fraseologiens plass i ordbøker for innvandrere. LexicoNordica 6: 65-78.

Kromann, Hans-Peder, Theis Riiber and Poul Rosbach. 1984. Überlegungen zu Grundfragen der zweisprachigen Lexikographie. Wiegand, Herbert Ernst (Ed.). 1984. Studien zur neuhochdeutschen Lexikographie V. Germanistische Linguistik 3-6: 159-238. Hildesheim/New York: Olms.

Kromann, Hans-Peder, Theis Riiber and Poul Rosbach. 1991. Principles of Bilingual Lexicography. Hausmann, Franz Josef, Oskar Reichmann, Herbert Ernst Wiegand and Ladislav Zgusta (Eds.). 1989-1991. Wörterbücher. Ein internationales Handbuch zur Lexikographie/Dictionaries. An International Encyclopedia of Lexicography/Dictionnaires. Encyclopédie internationale de lexicographie: 2711-2728. Handbücher zur Sprach- und Kommunikationswissenschaft 5.1-5.3. Berlin/New York: Walter de Gruyter.

Mikkelsen, Hans Kristian. 1992. What Did Shcherba Actually Mean by "Active" and "Passive" Dictionaries? Hyldgaard-Jensen, Karl and Arne Zettersten (Eds.). 1992. Symposium on Lexico- 
graphy V. Proceedings of the Fifth International Symposium on Lexicography May 3-5, 1990, at the University of Copenhagen: 25-40. Tübingen: Max Niemeyer.

Mugdan, Joachim. 1992a. Zur Typologie zweisprachiger Wörterbücher. Meder, Gregor and Andreas Därner (Eds.). 1992. Worte, Wörter, Wörterbücher: Lexikographische Beiträge zum Essener Linguistischen Kolloquium: 25-48. Tübingen: Max Niemeyer.

Mugdan, Joachim. 1992b. On the Typology of Bilingual Dictionaries. Hyldgaard-Jensen, Karl and Arne Zettersten (Eds.). 1992. Symposium on Lexicography V. Proceedings of the Fifth International Symposium on Lexicography May 3-5, 1990, at the University of Copenhagen: 17-24. Tübingen: Max Niemeyer.

Shcherba, L.V. 1940. Towards a General Theory of Lexicography. International Journal of Lexicography 8(4): 315-350, 1995.

Tarp, Sven. 1992. Prolegomena til teknisk ordbog. Ph.D. Dissertation. Århus: Spansk Institut. Handelshøjskolen i Århus. <http://www.lng.hha.dk/dml/spa/phd.pdf >.

Tarp, Sven. 1994. Funktionen in Fachwörterbüchern. Bergenholtz, Henning and Buchard Schaeder (Eds.). 1994. Fachlexikographie. Fachwissen und seine Repräsentation in Wörterbüchern: 229-246. Tübingen: Gunter Narr.

Tarp, Sven. 1995. Wörterbuchfunktionen: Utopische und realistische Vorschläge für die bilinguale Lexikographie. Wiegand, H.E. (Ed.). 1995. Studien zur zweisprachigen Lexikographie mit Deutsch II: 17-51. Lexicographica. Series Maior 110. Hildesheim/New York: Olms.

Tarp, Sven. 1998. Leksikografien på egne ben. Fordelingsstrukturer og byggedele i et brugerorienteret perspektiv. Hermes, Journal of Linguistics 21: 121-137.

Tarp, Sven. 1999. Lørnerordbøger for indvandrere og andet godtfolk. LexicoNordica 6: 107-132.

Tarp, Sven. 2000. Theoretical Challenges to LSP Lexicography. Lexikos 10: 189-208.

Tarp, Sven. 2002. Translation Dictionaries and Bilingual Dictionaries - Two Different Concepts. Journal of Translation Studies 7: 57-82.

Tarp, Sven. 2003. Basic Elements of Lexicographic Theory/Éléments de base de la théorie lexicographique. Emejulu, James Duplessis (Ed.). 2003. Éléments de lexicographie gabonaise. Tome II: 7-35. New York: Jimacs-Hillman.

Tarp, Sven. 2004. Basic Problems of Learner's Lexicography. Lexikos 14: 222-252.

Zöfgen, E. 1994. Lernerwörterbuch in Theorie und Praxis: Ein Beitrag zur Metalexikographie mit besonderer Berücksichtung des Französischen. Lexicographica. Series Maior 59. Tübingen: Max Niemeyer. 